\title{
COMPARATIVE ANALYSIS OF THE MECHANICAL PERFORMANCE OF TIMBER TRUSSES STRUCTURAL TYPOLOGIES APPLYING COMPUTATIONAL INTELLIGENCE
}

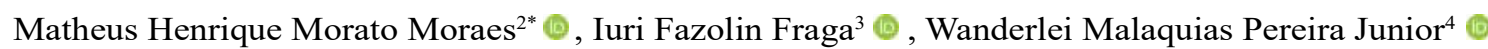 \\ and André Luis Christoforo ${ }^{5}$
}

\footnotetext{
${ }^{1}$ Received on 06.07.2021 accepted for publication on 19.10.2021.

${ }^{2}$ Universidade Federal de São Carlos, Programa de Pós-Graduação em Engenharia Civil, São Carlos, SP - Brasil. E-mail: <matheus.h.h@ hotmail.com>.

${ }^{3}$ Universidade Federal de São Carlos, Programa de Pós-Graduação em Engenharia Civil, São Carlos, SP - Brasil. E-mail: <iurifraga@ outlook.com>.

${ }^{4}$ Universidade Federal de Catalão, Departamento de Engenharia Civil, Catalão, GO - Brasil. E-mail: <wanderlei_junior@ufcat.edu.br>. ${ }^{5}$ Universidade Federal de São Carlos, Departamento de Engenharia Civil, São Carlos, SP - Brasil. E-mail: <alchristoforo@ufscar.br>.

*Corresponding author.
}

\begin{abstract}
Timber application is viable in constructive systems because of its mechanical properties, suitable for structural applications in engineering. Timber is even more interesting to use since it is a renewable source. Among its several applications, timber is widely used in roofing structures, with several typologies of trusses. Therefore, it is necessary to understand the behavior of plane truss in different loading conditions, including dead load, service load, and wind suction load. The mechanical performance of two trusses (Pratt and Scissor) was analyzed and compared, according to the Brazilian standard of timber structures ABNT NBR 7190 (1997) (methods and calculus premises), with the finite element method, an algorithm of swarm intelligence optimization (structure weight minimization), and a parametric study. Based on minimum weight and maximum displacement as a function of span variation, Pratt typology presented lower weight (3-19\%) when compared with Scissor, under the same span and loading conditions. Regarding maximum displacements, Pratt typology presented lower displacement values than the Scissor typology. The difference between these values ranged from two to seven times, indicating that Scissor typology can better distribute normal loads (maximum displacement closer to the normative limit displacement). Variance analysis ( $5 \%$ of significance) confirmed these results.
\end{abstract}

Keywords: Pratt; Scissor; Optimization.

\section{ANÁLISE COMPARATIVA DO DESEMPENHO MECÂNICO DE TIPOLOGIAS ESTRUTURAIS DE TRELIÇAS DE MADEIRA APLICANDO INTELIGÊNCIA COMPUTACIONAL}

\begin{abstract}
RESUMO - Aplicação da madeira é viável em sistemas construtivos devido a suas propriedades mecânicas, que são compatíveis com as aplicações estruturais na engenharia. A madeira é ainda mais interessante de se usar, uma vez que é uma fonte renovável. Dentre as diversas aplicações, a madeira é amplamente utilizada em estruturas de cobertura, com várias tipologias de treliças. Portanto, deve-se entender o comportamento das treliças planas em diferentes condições de carregamento, incluindo carga de peso próprio, carga de serviço e carga de sucção de vento. O desempenho mecânico de duas treliças (Pratt e Scissor) foi analisado e comparado, de acordo com a norma Brasileira de estruturas de madeira ABNT NBR 7190 (1997) (métodos e premissas de cálculo), com o método dos elementos finitos, um algoritmo de otimização de inteligência de enxame (minimização do peso da estrutura) e um estudo paramétrico. Com base no peso mínimo e no deslocamento máximo em função da variação do vão, a tipologia Pratt apresentou um peso menor (3-19\%) quando comparada com a Scissor, sob a mesma condição de carregamento e vãos. Em relação aos deslocamentos máximos, a tipologia Pratt
\end{abstract}




\begin{abstract}
apresentou valores de deslocamento menores do que a tipologia Scissor. A diferença entre estes valores variou de duas a sete vezes, indicando que a tipologia Scissor distribui melhor os esforços normais (deslocamentos máximos mais próximos do deslocamento limite normativo). Esses resultados foram confirmados pela análise de variância (5\% de significância).
\end{abstract}

Palavras-Chave: Pratt, Scissor, Otimização.

\section{INTRODUCTION}

Timber has been used as a structural material since ancient times, for it is not only renewable (Bita and Tannert, 2018), but it also has good mechanical properties and is easy to handle with simple tools. This material has been widely used in Structural Engineering (Mam et al., 2020) and mainly in projects of rural buildings (roofing structures).

Regarding sustainability representation, the American agency Energy Information Administration - EIA (2011) states that, until 2017, construction sectors responded for $40 \%$ of greenhouse gas emission (Mayencourt and Mueller, 2020).

Kumar et al. (2016) claim that the truss structural system is widely used in roofs of residential and industrial buildings because it can overcome large spans. Timber truss is prevalent in roofing systems, with several geometric typologies. Therefore, we must understand the behavior of typologies to use them in engineering projects.

Regardless of the material selected for the structural system, designing a structural part is a hard and time-consuming task that allows for the design engineer to determine ideal conditions (mass reduction combined with normative requirements for mechanical performance) of a structural system. This task is complex, since these objectives so-called "ideal goals" are conflicting. As an example, reducing the mass or volume of a structure implies reducing its stiffness (Lemonge et al., 2021) and result in greater displacements.

In structural projects, computational science was essential for designers to act quickly regarding development, scale reproduction, and improving test capacity and refinement.

With this evolution, structural optimization became a viable tool, and nowadays it is applied in several structural systems. Regarding timber structures, it is possible to observe some applications in timber beams (Mayencourt et al., 2017; Pech et al., 2019; Schietzold et al., 2021), braced frames in timber (Mam et al., 2020), and timber trusses (Villar et al., 2016; Villar-García et al., 2019; Ching, 2020). Few studies have addressed the optimization of trussed structures (or other structural systems) that follow the fulfillment normative performance requirements to compare typologies which are generally used in structural projects.

In Optimization, there are two types of algorithms: probabilistic and deterministic. The probabilistic model incorporates aspects of random variations in its formulations (Amaran et al., 2016). Given a specific input dataset, the procedure executed by the algorithm of a deterministic method will always reproduce the same output (Lin et al., 2012). Deterministic methods can conduct or approach the global minimum values of the Objective Function (OF), but since derivates of the OF are hard to obtain, they have a high computational cost (Lin et al., 2012; Segovia-Hernández et al., 2015). Regardless, deterministic methods achieve the global minimum of the function with less iterations than probabilistic methods (Huang et al., 2017).

Probabilistic optimization technique, has a subdivision of methods called bio-inspired, as their mathematical formulation is inspired by the nature. This subgroup includes the Firefly Algorithm (FA), which is prevalent in structural optimization processes (Gandomi et al., 2011; Lieu et al., 2018; Pereira et al., 2020; Talatahari et al., 2014).

From the viable optimal design perspective, optimization models are divided into three basic strands: a) Section Optimization; b) Shape Optimization; and c) Topology Optimization (Zhou et al., 2004).

Several typologies are used to design timber roofing structures, with emphasis on Pratt and Scissor (Gomes, 2020). However, it is hard to accurately compare mechanical performance with the usual design strategy and to choose the most suitable

Revista Árvore 2022;46:e4604 
method for a design. Therefore, this research intended to assess and to compare the mechanical performances of Pratt and Scissor typologies, with the aid of the Finite Element Method (FEM), the standard premises and the calculation methods from ABNT NBR 7190 (1997), the Firefly Algorithm (FA) (minimization of structural weight), and a parametric study [variation of the span (L) and of the horizontal distance (B) and vertical distance $(\mathrm{H})$ between nodes].

\section{MATERIAL AND METHODS}

To design timber trusses, precepts were used according to ABNT NBR 7190 (1997). The FA, the penalization method and the calculation of the $\mathrm{OF}$ were used alike and are presented below, including details of the parametric study and description of the statistic tool used to compare mechanical behavior between the two typologies considered.

Notably, the classic formulation of the FEM was considered in the deduction of stiffness matrix of the truss bar element (two nodes and four degrees of freedom in all). Based on the solution of the system of equilibrium equation (equilibrium between external and internal nodal loads) of the FEM, nodal displacements, specific strains, stresses, and normal loads on each truss bar were determined. Stresses and normal loads were essential for the structure design.

\subsection{Algorithm used for truss bars optimization}

The Firefly Algorithm (FA) was used, a bioinspired probabilistic optimization proposed by Yang (2008). FA is a method of population characteristic, in which one particle walks through the sample space searching for the optimal viable solution. In this method, concepts of random variables are used to generate the initial population, which is a random event limited by the problem (Yang, 2008).

This algorithm design was inspired by the bioluminescence and the influence of iteration between fireflies at mating season. Therefore, the FA optimization method is based on how fireflies can emit light and be perceived by other individuals of the same population.

To design the algorithm, Yang (2008) defined some precepts to aid in the development, including: all fireflies have a single genus and having a single gender, they are attracted to each other; the attraction capacity of each firefly is proportional to their own brightness, but larger distances between individuals decrease such capacity.

When the initial population is created, the firefly (design variable) begins a random walk (Equation 1), so that $\vec{x}$ "moves" according to an update function of the design variable ( $\vec{\omega})$, in which $\vec{x}$ is the vector of design variables, $\vec{\omega}$ is the vector of update function of $\vec{x}$, and $\mathrm{t}$ is the number of iterations.

$\vec{x}^{t+1}=\vec{x}^{t}+\vec{\omega}^{t}$

Based on this new direction, new positions and possible solutions for the optimal point of design are originated (Wang et al., 2017). Thus, fireflies move at each step of the iterative process (Equation 2).

$\omega^{t}=\beta\left(\vec{x}_{j}{ }^{t}-\vec{x}_{i}{ }^{t}\right)+\alpha(\vec{\eta}-0,5 \vec{\varepsilon})$ Eq.2

Where $\beta$ is a term of attractiveness between fireflies $i$ and $j ; \vec{x}_{i}$ is the firefly $i ; \vec{x}_{j}$ is the firefly $j ; \vec{\eta}$ is the vector of random numbers between 0 and $1 ; \alpha$ is the randomness factor (Equation 3); and $\vec{\varepsilon}$ is a unit vector.

Randomness factor $\alpha$ (Equation 3) follows an exponential decay behavior according to the number of iterations $t$, and $\theta$ is the constant decay of 0.98 .

$\alpha=\alpha_{\min }+\left(\alpha_{\max }-\alpha_{\min }\right) \cdot \theta^{t} \quad$ Eq.3

$\beta$ is the attractiveness between the swarm of fireflies (Equation 4), in which $\beta$ o is attractiveness for a distance $\mathrm{r}=0 ; \mathrm{r}_{\mathrm{ij}}$ is a Euclidean distance between fireflies $i$ and $j$ (Equation 5); and $\gamma$ is the parameter of light absorption (Equation 6).

$\beta=\beta_{0} e^{-\gamma r_{i j}^{2}} \cong \beta_{0} /\left(1+\gamma r_{i j}^{2}\right)$

Eq.4

$r_{i j}=\left\|\vec{x}_{i}-\vec{x}_{j}\right\|=\sqrt{\sum_{k=1}^{d}\left(\vec{x}_{i, k}-\vec{x}_{j, k}\right)^{2}}$

$\gamma=1 /\left(x_{\max }-x_{\min }\right)^{2}$

Where $k$ is the $\mathrm{k}$-th component of the design vector variable $\vec{x} ; d$ is the amount of design variables; $x_{\max }$ is the maximum of design variables; and $x_{\min }$ is the minimum of design variables.

FA or any other probabilistic method of optimization requires attention in defining algorithm parameters (attractiveness: $\beta$ and $\gamma$; randomness: $\alpha$ ). 
Parameter $\gamma$ is the attractiveness variation $\{\gamma \in$ $[0, \infty)\}$, essential to determine convergence speed and algorithm behavior. It mostly ranges between 0.1 and 10 (Yang, 2008).

\subsubsection{Optimization algorithm parameters}

Input parameters of FA were based on the study by Pereira et al. (2020). In our study, a total population $\left(N_{p o p}\right)$ of 15 individuals, randomly generated, were considered. All parameters were based on the sensitivity study by Pereira et al. (2020), including: 500 generations $\left(N_{g e n}\right)$, Attractiveness between fireflies $(\beta o)$ of 0.90 , Minimum randomness factor $\left(\alpha_{\text {min }}\right)$ of 0.20 , Maximum randomness factor $\left(\alpha_{\max }\right)$ of 1.00 , and Penalty factor $\left(R_{p}\right)$ of $10^{5}$.

\subsubsection{OF}

Optimization intends to minimize the total weight of the structural system, considering constraints of nodal displacements, mechanical resistance of the bars, and geometric criteria that can cause lateral instability. Objective Function (OF) is the total weight of a truss (Equation 7), in which $A_{i}$. is the cross-section area of a bar $i$; $\rho_{i}$. is the density of the material; $\mathrm{L}_{0_{i}}$. is the length of truss bar $i$; and $n$ is the number of truss bars.

$$
O F\left(A_{i}, \rho_{i}, L_{0_{i}}\right)=\sum_{i=1}^{n} A_{i} \cdot \rho_{i} \cdot L_{0_{i}}
$$

Other factors besides weight must be considered to optimize truss manufacture. For example, in industrial manufacturing, it is often more interesting to produce similar elements (same sections) than several sections. This and other aspects can affect the cost of the structure (Šilih et al., 2010; Jelusic and Kravanja, 2017). However, our study considers only the weight for optimization, focusing on the final weight of the truss.

For optimization problems, constraint restrictions must be treated. Therefore, the external penalty technique was used (Kuri-Morales and GutiérrezGarcía, 2002; Yeniay, 2005), in which the OF is modified to become a pseudo OF, where $g_{j}$. represents inequality constraints and $h_{k}$ restrictions on equality. For penalty, the OF used the complete form of the penalty method (Equation 8), resulting in Penalized OF (W) (Equation 9).
$P(\vec{x})=\sum_{j=1}^{m} \max \left[0, g_{j}(\vec{x})\right]^{2}+\sum_{k=1}^{n}\left[h_{k}(\vec{x})\right]^{2}$

Eq.8

$W\left(A_{i}, \rho_{i}, L_{0_{i}}, \overrightarrow{x_{i}}\right)=O F\left(A_{i}, \rho_{i}, L_{0_{i}}\right)+R_{p} P(\vec{x}) \quad$ Eq.9

Note that, $P(\vec{x})$ (Equation 8) is the static outer penalty function $j ; k$ is $\mathrm{j}$-th inequality constraints and k-th equality constraints, respectively; $m, n$ are the total number of inequality and equality constraints, respectively; $\vec{x}$ is the solution vector (random population); $g, h$ are the set of inequality and equality constraints; and $W(\vec{x})$ is the penalized OF.

\subsection{Description of trusses and design variables}

This study analyzed two plane trusses: Pratt and Scissor. Trusses were divided into seven spans with a total length of $5,7.5,10,12.5,15,17.5$, and 20 meters, based on Gomes (2020). For each of the trusses, the optimization algorithm was performed 30 times to obtain a dispersion of the results. Nodal distances ( $B=L / 4$ and $H=L / 8$ ) were used for both typologies, and design variables (bar position) considered $\vec{x}_{1}, \vec{x}_{2}$, $\vec{x}_{3}, \vec{x}_{4}$ and $\vec{x}_{5}$ (Figure 1).

$\vec{x}_{i}$ is the generic design variable (Equation 10) in which $\vec{x}_{i}$ is the variable vector of design $i ; b_{i}$ is the thickness of the cross section of variable $i$; and $h_{i}$ is the height of the cross section of variable $i$. For each type of bar, a design variable was used: $\vec{x}_{1}$ for the bottom chord, $\vec{x}_{2}$ for the top chord, $\vec{x}_{3}$ for secondary vertical bars, $\vec{x}_{4}$ for the main vertical bars, and $\vec{x}_{5}$ for diagonal bars.

$\vec{x}_{i}=\left(b_{i} ; h_{i}\right)$

For optimization problems, a set of distinct variables was considered, in which each variable had an ordered set of values (Hsu, 1985). Therefore, we considered nominal values for coniferous sawn timber according to ABNT NBR ISO 3179 (2011). Based on the standard nominal values, variations of the design variables were: thickness of the crosssection of a generic bar $i\left(b_{i}\right)$ assuming values of $[16,19,22,25,32,38,50,63,75,100,125,150,175$, 200,250 , and $300 \mathrm{~mm}$ ] and cross-section height of a generic bar $i\left(h_{i}\right)$ assuming values of $[75,100,115$, $125,150,160,175,200,225,250,275$, and $300 \mathrm{~mm}]$.

For optimization process, coniferous timber was considered and belonging to the resistance class $\mathrm{C} 30$, 

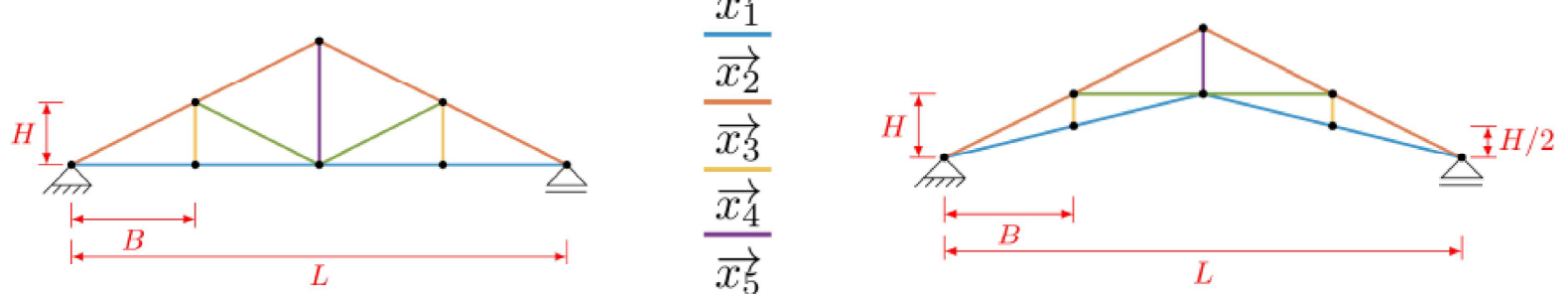

Figure 1 - Generic representation of the nodal distances of trusses. Figura 1 - Representação genérica das distâncias nodais das treliças.

whose properties are presented in the ABNT NBR 7190 standard (1997). Sawn timber was classified as permanent loading class, with moisture class I, $12 \%$ equilibrium moisture, and 1st category timber.

\subsection{Loads and limit states}

The vertical loads to which the trusses are submitted consist of roofing load for a sandwich tile (G) of $150 \mathrm{~N} / \mathrm{m}^{2}$; structure dead load (DL) of $150 \mathrm{~N} /$ $\mathrm{m}^{2}$; service load $(\mathrm{S})$ of $25 \mathrm{~N} / \mathrm{m}^{2}$; and wind suction load (W) of $600 \mathrm{~N} / \mathrm{m}^{2}$.

To verify Limit States, three combinations were adopted based on the normative requirements of ABN NBR 7190 (1997), two in Ultimate Limit State (ULS): combination $1(1.3 \mathrm{DL}+1.3 \mathrm{G}+1.4 \mathrm{~S}+0.7$ $\mathrm{W})$; combination $2(1.0 \mathrm{DL}+1.0 \mathrm{G}+0.56 \mathrm{~S}+1.4$ $\mathrm{W})$; and one for the Serviceability Limit State (SLS): combination $3(1.0 \mathrm{DL}+1.0 \mathrm{G}+0.3 \mathrm{~S}+0.2 \mathrm{~W})$. Soon Afterwards, such combinations were checked in all OF constraints.

Based on the area of influence and considering a distance of 5 meters between gantries, distributed loads were transformed into nodal loads. The IDE (Integrated Development Environment) of the MATLAB ${ }^{\circledR}$ software was used for structural analysis and optimization.

\subsection{Design constraints}

Constraints $\left(g_{j}(\vec{x})\right)$ (Equations 11 to 15$)$ where $\mathrm{i}$ is a generic bar $\left(i=1, \ldots, n_{\text {bars }}\right), n_{\text {bars }}$ is the number of analyzed truss bars , $\mathrm{n}$ is a generic node $\left(n=1, \ldots,, n_{\text {nodes }}\right)$, and $n_{\text {nodes }}$ is the number of analyzed truss joints . $g_{j}(\vec{x})=\sigma_{i} / \sigma_{\text {lim }}-1 \leq 0$

Eq.11

$g_{j}(\vec{x})=u_{n} / u_{l i m}-1 \leq 0$

$g_{j}(\vec{x})=\lambda_{i} / \lambda_{\text {lim }}-1 \leq 0$

$g_{j}(\vec{x})=A_{m i n} / A_{i}-1 \leq 0$

$g_{j}(\vec{x})=b_{\min } / b_{i}-1 \leq 0$

ULS (Equation 11) was checked for normal stresses $\left(\sigma_{i}\right)$ (tensile and compression), in which $\sigma_{\text {lim }}$ is the normal stress limit. SLS (Equation 12) was also checked, in which $u_{n}$ is a nodal displacement and $u_{l i m}$ is the displacement limit, with $u_{\text {lim }}=\mathrm{L} / 200$ (ABNT NBR $7190,1997)$, in which $L$ is the span of the analyzed structural system. The geometric constraint (Equation 13) of bars based on the slenderness index $\left(\lambda_{i}\right)$ was also analyzed, in which $\lambda_{\text {lim }}$ is the limit slenderness index, with 140 as maximum value according to ABNT NBR 7190 (1997). Geometric constraints generated by the ratio between the cross-sectional area $\left(A_{i}\right)$ and minimum area $\left(A_{\min }\right)$ of a bar (Equation 14), with a minimum of $50 \mathrm{~cm}^{2}$ for the cross-sectional area (ABNT NBR 7190, 1997). Finally, we analyzed geometric constraints (Equation 15) that associate the thickness $\left(b_{i}\right)$ and minimum thickness $\left(b_{\text {min }}\right)$ of a given bar. ABNT NBR 7190 (1997) limits the minimum thickness to $5 \mathrm{~cm}$ for main bars.

\subsection{Analysis of Variance (ANOVA)}

The analysis of variance (ANOVA), with 5\% significance level, was used to verify potential differences in the mechanical performance of the 
Table 1 - Summary of results obtained from truss optimization process.

Tabela 1 - Resumo dos resultados obtidos do processo de otimização das treliças.

\begin{tabular}{|c|c|c|c|c|c|c|c|}
\hline Truss & $W_{\max }(\mathrm{kg})$ & $W_{\min }(\mathrm{kg})$ & A (kg) & $\mu$ (kg) & $\overline{\overline{\mathbf{x}}} \mathbf{( k g )}$ & $\sigma(\mathrm{kg})$ & FR (\%) \\
\hline$\overline{P-5}$ & 95.32 & 76.31 & 19.00 & 83.02 & 83.70 & 5.18 & 100 \\
\hline$P-7.5$ & 150.80 & 117.72 & 33.07 & 131.88 & 133.08 & 9.14 & 100 \\
\hline$P-10$ & 243.81 & 170.48 & 73.32 & 207.76 & 205.82 & 18.45 & 100 \\
\hline$P-12.5$ & 442.25 & 372.12 & 70.12 & 393.06 & 394.49 & 15.11 & 100 \\
\hline$P-15$ & 633.63 & 487.66 & 145.97 & 526.15 & 533.28 & 32.05 & 100 \\
\hline$P-17.5$ & 785.89 & 656.04 & 129.85 & 699.74 & 706.44 & 31.29 & 100 \\
\hline$P-20$ & 1115.25 & 967.45 & 147.82 & 1029.39 & 1031.56 & 31.88 & 100 \\
\hline$S-5$ & 84.99 & 68.79 & 16.19 & 73.95 & 74.64 & 4.57 & 100 \\
\hline$S-7.5$ & 167.41 & 116.24 & 51.16 & 135.86 & 134.44 & 10.54 & 100 \\
\hline$S-10$ & 285.41 & 239.45 & 45.95 & 254.50 & 256.80 & 11.35 & 100 \\
\hline S - 12.5 & 454.79 & 354.72 & 100.06 & 377.72 & 381.64 & 19.00 & 100 \\
\hline$S-15$ & 607.49 & 524.80 & 82.68 & 549.78 & 552.49 & 17.17 & 100 \\
\hline$S-17.5$ & 878.11 & 755.23 & 122.87 & 786.61 & 792.86 & 27.48 & 100 \\
\hline$S-20$ & 1091.40 & 1017.40 & 74.00 & 1042.39 & 1044.40 & 19.88 & 100 \\
\hline
\end{tabular}

two typologies. For this, the ANOVA was considered on the results of constraints with normal loads and displacements. For each span $(5.00,7.50,10.00, \ldots$, $20.00 \mathrm{~m}$ ) considering a type of constraint (stress or displacement), we verified whether both typologies (Pratt and Scissor) were statistically equivalent to each other regarding the mean restriction. According to ANOVA, p-value (probability p) greater than or equal to the significance level implies an equivalence of restriction means, while lower significance implies a non-equivalence.

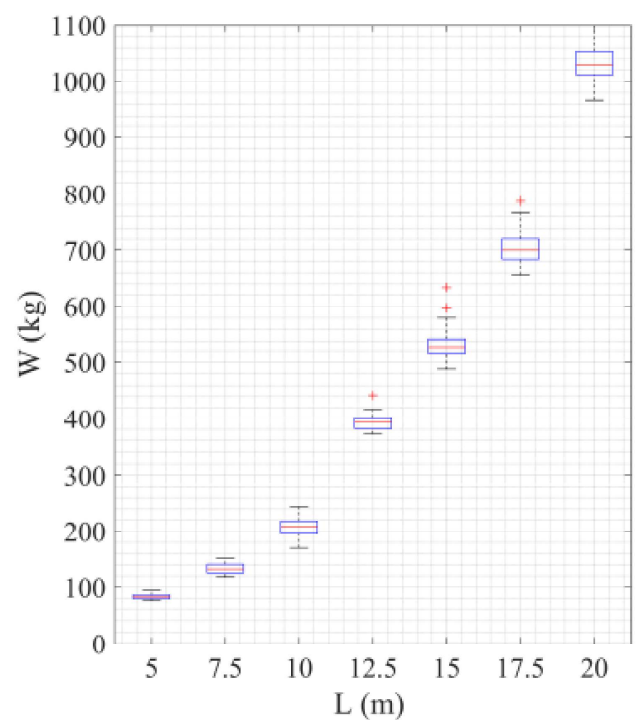

Following ANOVA, the Anderson-Darling test was also used with 5\% significance level to verify the normality in the distribution of ANOVA residues. According to the test, p-value greater than or equal to the significance level implies normality of residue distribution, therefore validating the ANOVA results.

\section{RESULTS}

This section shows the results obtained from the optimization process of trusses. Results (Table 1) of

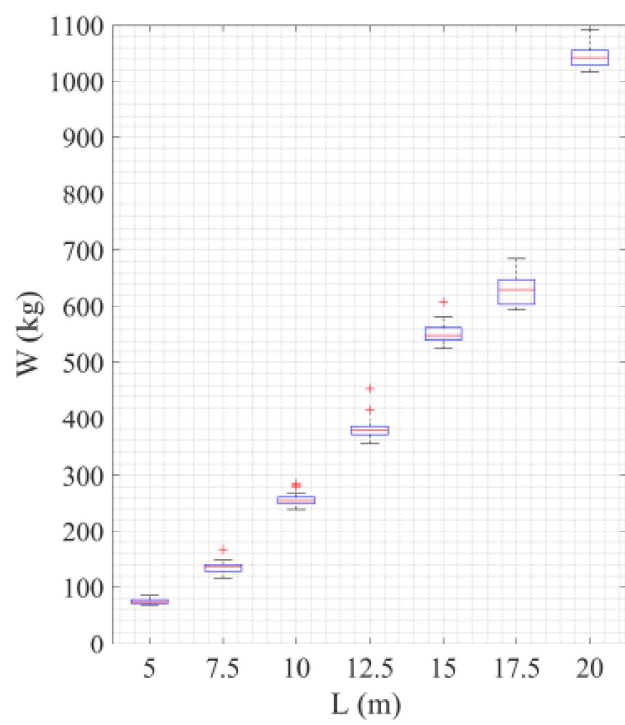

Figure 2 - Box plot of Minimum weight (W) of trusses as a function of the variation of span L.

Figura 2 - Box plot do Peso mínimo (W) das treliças em função da variação do vão $L$.

\section{Revista Árvore 2022;46:e4604}



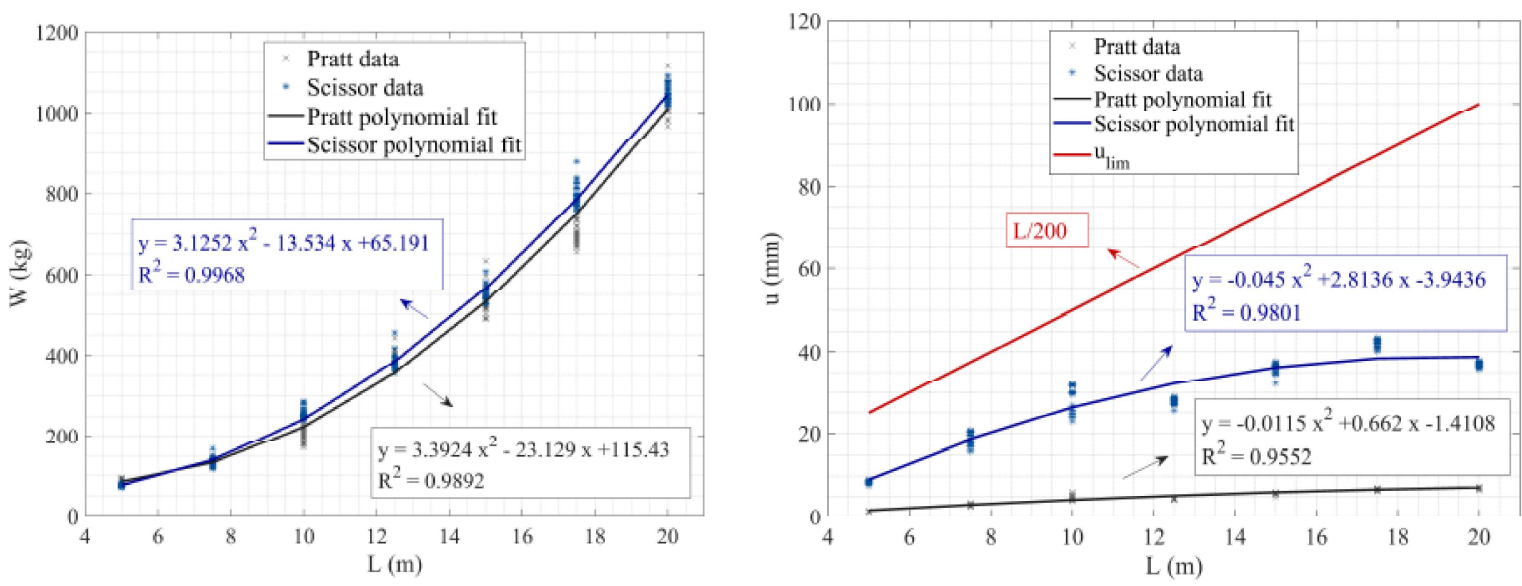

Figure 3 - Curves of: a) Minimum weight (W) of trusses as a function of span (L); and b) Maximum displacement as a function of span (L). Figura 3 - Curvas do: a) Peso mínimo (W) das treliças em função do vão (L); e b) Máximo deslocamento (u) em função do vão (L).

the 30 optimization processes for different trusses can be observed considered, in which $W_{\max }$ and $W_{\min }$ represent the maximum and minimum values of the penalized OF, respectively; amplitude (A), median $(\mu)$, mean $(x)$, standard deviation $(\sigma)$, and feasibility rate (FR) represent the ratio between tests with satisfied constraints and total number of tests (30). To sum the results, trusses of type $\mathrm{x}-\mathrm{y}$ will be identified, where " $\mathrm{x}$ " is the typology (P for Pratt and $\mathrm{S}$ truss for
Scissor truss) and "y" is the truss span in meters $(5$, $7.5,10,12.5,15,17.5$, and 20).

With Box plot, we observed the weight variation of Pratt and Scissor trusses as a function of the span (L) (Figure 2).

After optimization analyses, we created curves (via quadratic regression models) of the $\mathrm{OF}$ (W minimum weight) as a function of the span (L) for

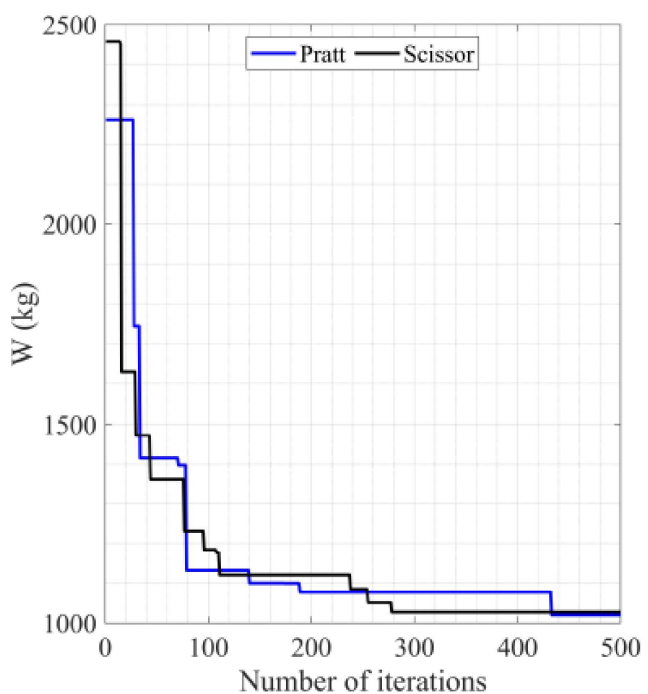

Figure 4 - Convergence curves for minimum weight (W) for P-5, P-20, S-5, and S-20.

Figura 4 - Curvas de convergência para o peso minimo (W) para $P-5, P-20$, S-5 e $S-20$.

Revista Árvore 2022;46:e4604 
conditions delimited in this study (Figure 3a). Such curves (Figure 3a) allow estimating the minimum weight of the trusses as a function of span, even for $\mathrm{L}$ values not included here.

Once we had the total weight of the trusses, an analysis of the maximum displacement of each truss was required to ensure the structure would follow normative requirements. Similarly, truss weight curves were created to predict the maximum displacement (Figure 3b).

We obtained the convergence curve from the best response among 30 repetitions of the weight of the trusses of 5 and 20 meters (Figure 4).

\subsection{Assessment of stress constraints}

Constraints showed how the tension, displacement, slenderness, area, and dimensions of cross-sections are close to the established limit. Restrictions (g values) with values closer to 0 indicate more loaded bars (stress). Stress constraints were considered the combination 1 (ULS combination, with the service load as the main accidental load) and combination 2 (ULS combination, with the wind load as the main accidental load).

Based on the ANOVA of normal stress constraints, we verified major differences between typologies. Normal stress restrictions had p-values between 0.004 and 0.046, lower than the significance level $(\alpha=0.05)$, indicating great differences between means. P-values of the Anderson-Darling normality test on ANOVA residues were greater than $0.05(5 \%)$, thus validating the ANOVA model. Moreover, Pratt truss had mean values between -0.9087 and -0.8333 , while Scissor truss had values between -0.7989 and -0.6646 .

\subsection{Assessment of displacement constraints}

Based on the analysis of variance (ANOVA) of displacement constraints, we verified major differences between typologies. P-values of the Anderson-Darling normality test were higher than the significance level, which validates the ANOVA model. All trusses had p-values between 0.002 and 0.004. Displacement restrictions presented $p$-values lower than the significance level $(\alpha=0.05)$, indicating significant differences between the mean values of such restrictions. The Pratt truss had mean values between -0.9875 and -0.9380 , while the Scissor truss values between -0.7457 and -0.6545 .

\section{DISCUSSIONS}

Our results help to understand the mechanical behavior of Pratt and Scissor trusses. From the Box plot (Figure 2) of weight variation as a function of span (L), we observed that the dispersion of the results increases according to the increase of the $\mathrm{L}$ parameter. This variation occurs because when the span increases, loads also increase, and it is harder to find viable minimum values through optimization.

A graph of the minimum weights of trusses (Figure 3a) shows that trusses differ according to the spans. As a result, the Pratt truss presented OF values (OF - minimum weight) between 3\% and 19\% lower in relation to the Scissor truss.

Regarding displacement (Figure 3b), both trusses are within the ABNT NBR 7190 (1997) standard. Thus, based on resulting curves, maximum displacements of the Pratt truss are two to seven times lower than those of the Scissor truss.

Regarding convergence of the best result (Figure 4), the Pratt truss was the first to converge to the minimum weight for the $5 \mathrm{~m}$ span truss. For the 20 $\mathrm{m}$ span truss, Scissor converged firstly. P-5 (Pratt with $5 \mathrm{~m}$ span) converged in 160 iterations, with 456 iterations for S-5, 433 iterations for P-20, and 278 iterations for $\mathrm{S}-20$, based on a tolerance rate of $10^{-2}$.

The results of the stress constraints evaluation showed that the Scissor truss presented better distribution of normal loads (mean value of the constraint closer to 0 ), further using the load capacity of the trussed structures. Analyzing the results of the displacement constraints evaluation showed that Scissor is more displaceable than Pratt, and that both trusses respected the limit (L/200) established by the Brazilian standard ABNT NBR 7190 (1997). This fact allows choosing the best truss for roofing structures.

Normal stress and displacement constraints results showed that, the normal stresses guided the design for Pratt truss, whereas regarding the Scissor truss, displacements were the main guide.

\section{CONCLUSION}

Our results showed that the Scissor truss had greater weight, since the curve (relation between minimum weight and span) of the Pratt truss provided

Revista Árvore 2022;46:e4604 
OF values (minimum weight) between $3 \%$ and $19 \%$ lower than the Scissor truss. Regarding displacementspan curves, the Pratt truss presented displacements between two and seven times lower than Scissor truss, and nodal displacements of Scissor trusses were closer to the L/200. Therefore, the Pratt truss was less displaceable.

This establishes parameters for choosing between the two typologies. Since both trusses satisfy the design criteria, and the designer can choose between better mechanical performance, displaceability and material consumption.

For broader results, other common typologies for performance analysis must be studied, focusing on properties of hardwood timber (dicotyledons) and other optimization methods.

\section{AUTHOR CONTRIBUTIONS}

A. L. Christoforo conceptualized and supervised the analyses, supervised the statistical analysis of the experimental data; M. H. M. Moraes was in charge of the experiment organization, analyses running, data collection, statistical analysis, wrote the initial draft of the manuscript, and finalized the manuscript, I. F. Fraga assisted the data collection; and W. M. Pereira Junior revised the statistical analysis, and finalized the manuscript. All authors approved the final version of the manuscript.

\section{ACKNOWLEDGEMENTS}

This study was partially supported by the Coordination for the Improvement of Higher Education Personnel (CAPES) - Brazil - Finance Code 001

\section{REFERENCES}

Amaran S, Sahinidis NV, Sharda B, Bury SJ.

Simulation optimization: a review of algorithms and applications. Ann Oper Res. 2016;240:351-80. doi: 10.1007/s10479-015-2019-x

Associação Brasileira de Normas Técnicas - ABNT. Madeira serrada de coníferas - Dimensões nominais - NBR ISO 3179. Rio de Janeiro - RJ: ABNT; 2011.

Associação Brasileira de Normas Técnicas - ABNT. Projeto de estruturas de madeira - NBR 7190. Rio de
Janeiro - RJ: ABNT; 1997

Bita HM, Tannert T. Numerical optimisation of novel connection for cross-laminated timber buildings. Engineering Structures. 2018;175:273-83. doi: $10.1016 /$ j.engstruct.2018.08.020

Ching HYE. Truss topology optimization of steeltimber structures for embodied carbon objectives [thesis]. Massachusetts Institute of Technology MIT; 2020.

Energy Information Administration - EIA. Emission of Greenhouse Gases in the United States 2009. Washington, DC: U.S. Energy Information Administration - EIA; 2011.

Gandomi AH, Yang X-S, Alavi AH. Mixed variable structural optimization using Firefly Algorithm. Computers \& Structures. 2011;89:2325-36. doi: 10.1016/j.compstruc.2011.08.002.

Gomes AFF. Influência do valor médio do módulo de elasticidade à compressão paralela às fibras no projeto de treliças em madeira [thesis]. Universidade Federal de São Carlos - UFSCar; 2020.

Hsu CS. A discrete method of optimal control based upon the cell state space concept. J Optim Theory Appl. 1985;46:547-69. doi: 10.1007/BF00939159

Huang C, Hami AE, Radi B. Metamodel-based inverse method for parameter identification: elastic-plastic damage model. Engineering Optimization. 2017;49:633-53. doi: 10.1080/0305215X.2016.1206537

Jelusic P, Kravanja S. Optimal design of timberconcrete composite floors based on the multiparametric MINLP optimization. Composite Structures. 2017;179:285-93. doi: 10.1016/j. compstruct.2017.07.062

Kumar JP, Kumar JDC, Kumar MP. Quantitative Study of Howe Truss (A- Type) and Parallel Chord Scissor Truss (B- Type) by Applying External Pre-Stressing. International Journal of Engineering Research \& Technology. 2016:5. doi: 10.17577/ IJERTV5IS010409

Kuri-Morales AF, Gutiérrez-García J. Penalty Function Methods for Constrained Optimization with Genetic Algorithms: A Statistical Analysis. In: Coello 
Coello CA, de Albornoz A, Sucar LE, Battistutti OC, editors. MICAI 2002: Advances in Artificial Intelligence, Berlin, Heidelberg: Springer; 2002, p. 108-17. doi: 10.1007/3-540-46016-0_12

Lemonge ACC, Carvalho JPG, Hallak PH, Vargas DênisEC. Multi-objective truss structural optimization considering natural frequencies of vibration and global stability. Expert Systems with Applications. 2021;165:113777. doi: 10.1016/j. eswa.2020.113777

Lieu QX, Do DTT, Lee J. An adaptive hybrid evolutionary firefly algorithm for shape and size optimization of truss structures with frequency constraints. Computers \& Structures. 2018;195:99112. doi: 10.1016/j.compstruc.2017.06.016

Lin M-H, Tsai J-F, Yu C-S. A Review of Deterministic Optimization Methods in Engineering and Management. Mathematical Problems in Engineering. 2012;2012:e756023. doi: $10.1155 / 2012 / 756023$

Mam K, Douthe C, Le Roy R, Consigny F. Shape optimization of braced frames for tall timber buildings: Influence of semi-rigid connections on design and optimization process. Engineering Structures. 2020;216:110692. doi: 10.1016/j. engstruct.2020.110692

Mayencourt P, Mueller C. Hybrid analytical and computational optimization methodology for structural shaping: Material-efficient mass timber beams. Engineering Structures. 2020;215:110532. doi: 10.1016/j.engstruct.2020.110532

Mayencourt PL, Giraldo JS, Wong E, Mueller CT. Computational Structural Optimization and Digital Fabrication of Timber Beams. Proceedings of IASS Annual Symposia 2017. 2017:1-10.

Pech S, Kandler G, Lukacevic M, Füssl J. Metamodel assisted optimization of glued laminated timber beams by using metaheuristic algorithms. Engineering Applications of Artificial Intelligence. 2019;79:129-41. doi: 10.1016/j. engappai.2018.12.010

Pereira LLM, Santos DC, Moraes MHM, Gonçalves Filho GM, Ancioto Junior EM, Pereira Junior WM, et al. Estudo de Sensibilidade do Algoritmo de Colônia de Vagalumes para um Problema de Engenharia Envolvendo Dimensionamento de
Treliças. Tend. Mat. Apl. Comput. 2020;21:583. doi: 10.5540/tema.2020.021.03.583

Schietzold FN, Graf W, Kaliske M. Multi-objective Optimization of Tree Trunk Axes in Glulam Beam Design Considering Fuzzy Probability Based Random Fields. ASCE-ASME J. Risk and Uncert in Engrg. Sys. Part B Mech. Engrg. 2021. doi: $10.1115 / 1.4050370$

Segovia-Hernández JG, Hernández S, Bonilla Petriciolet A. Reactive distillation: A review of optimal design using deterministic and stochastic techniques. Chemical Engineering and Processing: Process Intensification. 2015;97:134-43. doi: 10.1016/j.cep.2015.09.004

Šilih S, Kravanja S, Premrov M. Shape and discrete sizing optimization of timber trusses by considering of joint flexibility. Advances in Engineering Software. 2010;41:286-94. doi: 10.1016/j. advengsoft.2009.07.002

Talatahari S, Gandomi AH, Yun GJ. Optimum design of tower structures using Firefly Algorithm. The Structural Design of Tall and Special Buildings. 2014;23:350-61. doi: 10.1002/tal.1043

Villar JR, Vidal P, Fernández MS, Guaita M. Genetic algorithm optimisation of heavy timber trusses with dowel joints according to Eurocode 5. Biosystems Engineering. 2016;144:115-32. doi: 10.1016/j. biosystemseng.2016.02.011

Villar-García JR, Vidal-López P, Rodríguez-Robles D, Guaita M. Cost optimisation of glued laminated timber roof structures using genetic algorithms. Biosystems Engineering. 2019;187:258-77. doi: 10.1016/j.biosystemseng.2019.09.008

Wang H, Wang W, Zhou X, Sun H, Zhao J, Yu X, et al. Firefly algorithm with neighborhood attraction. Information Sciences. 2017;382-383:374-87. doi: 10.1016/j.ins.2016.12.024

Yang X-S. Nature-Inspired Metaheuristic Algorithms. 1o. Frome: Luniver Press; 2008.

Yeniay Ö. Penalty Function Methods for Constrained Optimization with Genetic Algorithms. Mathematical and Computational Applications. 2005;10:45-56. doi: $10.3390 /$ mca10010045

Zhou M, Pagaldipti N, Thomas HL, Shyy YK. An

Revista Árvore 2022;46:e4604 
integrated approach to topology, sizing, and shape optimization. Structural and Multidisciplinary
Optimization. 2004;26:308-17. doi: 10.1007/s00158003-0351-2

Revista Árvore 2022;46:e4604 